\title{
A PROGRAMOZÁS-TANULÁS EREDMÉNYESSÉGÉT BEFOLYÁSOLÓ KÉSZSÉGEK VIZSGÁLATA
}

\section{AN EXAMINATION OF SKILLS AFFECTING THE EFFECTIVENESS OF PROGRAMMING}

\author{
Pap-Szigeti Róbert ${ }^{1,2^{*}}$, Pásztor Attila ${ }^{3}$ \\ ${ }^{1}$ Kecskeméti Bolyai János Gimnázium, Magyarország \\ 2 Informatika Tanszék, GAMF Műszaki és Informatikai Kar, Neumann János Egyetem, Magyarország \\ 3 Informatika Tanszék, GAMF Műszaki és Informatikai Kar, Neumann János Egyetem, Magyarország \\ https://doi.org/10.47833/2020.3.CSC.004
}

\section{Kulcsszavak: \\ programozás algoritmizálás emelt szintű érettségi szövegértés}

\section{Keywords:}

programming algorithms

IT final exam reading comprehension

\section{Cikktörténet:}

Beérkezett 2020. október 19. Átdolgozva 2020. november 5 . Elfogadva 2020. november 8.

\begin{abstract}
Összefoglalás
A bemutatásra kerülő mérésben egyrészt a szövegértés és annak kritikus előfeltételeként a szóolvasás készsége fejlettségének hatását vizsgáltuk az algoritmizálási és programozási feladatokon mutatott teljesítményre. Másrészt arra kerestünk választ, hogy az emelt szintü érettségi programozási feladatainak sikeres megoldásában milyen szerepet játszanak az algoritmizálás készségei, a programnyelv elemeinek ismeret és a fejlesztökörnyezet használata. A középiskolás és mérnökinformatikus-hallgató mintán $(n=128)$ öt részteszttel felvett mérések eredményei alapján mutatjuk be a készségek egymásra épülését.
\end{abstract}

Abstract
In this article we examined the effect of the development of
reading comprehension and word reading skills on the
performance on understanding algorithm and programming
tasks. Additionally, we examined the role of algorithmization
skills, knowledge of programming language elements and the
use of the IDE in the successful solution of advanced graduation
programming tasks. Based on the results of our measurements
taken with five partial tests on the sample of high school and IT
engineering students ( $n=128$ ), we present the building of skills
on top of each other.

\section{Bevezetés}

A programozás alapvető készségeinek, az algoritmusok megértésének és alkalmazásának elsajátítása a tanulók, hallgatók széles körében szükséges a modern informatikai eszközök hatékony alkalmazásához. Bár tényleges programozást az informatikai eszközök alkalmazóinak csak kisebb hányada végez, az alkalmazások eredményes használatához gyakran összetett algoritmusok megjegyzésére és adaptálására van szükség. [1] [5]

Az ezredforduló előtt és környékén megjelenő tanulmányok jelentős része egy-egy módszer hatékonyságával foglalkozik. [3] [13] [17] A tanulmányok másik jelentős hányada vizsgálja a programozási készségek és az általános gondolkodási képességek kapcsolatát. [2] [6] [8] [15] Az

\footnotetext{
* Kapcsolattartó szerző. Tel.: +36 20421 9931; fax: +36 76516399

E-mail cím: pasztor.attila@gamf.uni-neumann.hu
} 
elmúlt másfél-két évtizedben a vizsgálatok részben azoknak az összetevőknek az azonosítására irányultak, amelyek a programozás ismeret-, készség- és motívumrendszerét alkotják. [7] [16] Korábbi vizsgálatainkban az előadás szerzői is vizsgálták a hallgatók programozással kapcsolatos motívumait, valamint a programozási készségek és az énkép változásait különböző oktatásszervezési módszerek alkalmazása esetén. [9] [11] [14]

\section{A vizsgálat kérdései}

A bemutatásra kerülő kutatás két alapvető kérdése az volt, hogy (1) a szóolvasás és az azt összetevőként felhasználó szövegértés kritikus előfeltétele-e az - emelt szintű érettségin elvárt algoritmiziálásnak; (2) alátámasztható-e, hogy a programozás emelt szintü érettségin elvárt készségei és ismeretei besorolhatók négy, filterjelleggel egymásra épülő komponensbe. [4] A filterjelleg két alapvető ismérve, hogy az alacsonyabb szintű komponens meghatározott küszöbszintje szükséges a magasabb szint müködéséhez, de a küszöbszintet meghaladó tudás egyéni különbségei már nem befolyásolják jelentősen a magasabb szintben mérhető egyéni különbségeket. Mivel a résztesztek értékelése nem összesztenderdizált skálán történik, ezért a küszöbszint nominális értéke az egyes változóknál eltérő lehet.

A feltételezett, egymásra épülő komponensek: (a) algoritmusok megértése, létrehozása, hibakeresése; (b) egy programnyelv elemeinek felidézése és alkalmazása kivitelezési feladatokban; (c) egy konkrét fejlesztőkörnyezet kezelése, hibaüzeneteinek értelmezése; (d) algoritmusok implementálása. [11]

\section{Módszerek}

\subsection{Minta}

A mérés mintájában $(n=128)$ olyan középiskolai tanulók és alapszakos hallgatók vettek részt, akik tananyaguk részeként tanulnak algoritmizálást és programozást. A középiskolai részminta tanulói informatika tagozatos csoportok illetve 12. évfolyamos, emelt szintű érettségire felkészítő csoportok tagjaként kerültek a vizsgálat mintájába, a többi résztvevő pedig mérnökinformatikus hallgatóként. A minta összetételét az (1. táblázat) mutatja be.

1. táblázat. A mérés mintájának megoszlása részminták és évfolyamok szerint

\begin{tabular}{|c|c|c|c|c|c|}
\hline & \multicolumn{4}{|c|}{ Középiskolai részminta } & \multirow{2}{*}{$\begin{array}{c}\text { BSc hallgatók } \\
\text { részmintája }\end{array}$} \\
\cline { 2 - 5 } & 9. évf. & 10. évf. & 11. évf. & 12. évf. & 34 fő \\
\hline Teljes minta & 22 fő & 21 fő & 23 fő & 28 fö & 29 fő \\
\hline $\begin{array}{c}\text { Programozás } \\
\text { részteszt mintája }\end{array}$ & 0 fő & 0 fő & 23 fő & 28 fő & 2 \\
\hline
\end{tabular}

A 9-10. évfolyam tanulói a programozás résztesztet (Id. 3.2. fejezet) nem oldották meg, mivel tananyagukban még nem szerepelt az összes szükséges elem. Szervezési okok miatt a BSc-s részminta elemszáma is 29 före szükült, így a programozási feladat eredményeit és összefüggéseit összesen 80 fő adatai alapján elemezzük (figyelembe véve a szükebb részminta eredményeinek eltérését a teljes mintáétól).

A minta összetétele, a részminták aránya jelentősen eltér az elömérés [11] mintájától, így azokkal nem vetjük össze az eredményeket.

\subsection{Mérőeszközök és a mérés körülményei}

A mérés eszközrendszere egy rövid kérdőívből és öt résztesztből állt. A kérdőív a besoroló változók mellett a programozáshoz és a szövegértéshez kapcsolódó énkép-összetevőket vizsgálta. A szóolvasás készségét mérő részteszt az országos kompetenciamérésben alkalmazott egyik tesztváltozat feladatai ${ }^{*}(86$ item) mellett a szakszókincsre vonatkozó feladatokat (18 item) tartalmazott (Cronbach- $\alpha=0,89)$. A további résztesztek a szerzők fejlesztései. A szövegértés

\footnotetext{
* https://www.oktatas.hu/kozneveles/meresek/keszseg_kepessegmeres/tesztfuzetek_javitokulcsok/uj_tesztfuzetek_2013tol
} 
résztesztje (16 item; Cronbach- $\alpha=0,71$ ) a szövegböl közvetlenül kiolvasható információk mellett a szövegböl való következtetési és a szövegre való reflektálási feladatokat tartalmazott. Az alacsonyabb reliabilitás feltehetően a plafoneffektus következménye ( $\bar{x}=81 \%$ pont), ugyanerre utal az eredmények balra elnyúló eloszlása is (Kolmogorov-Szmirnov $z=2,139 ; p<0,001$ ).

A további három részteszt (algoritmizálás; programnyelvi elemek és a fejlesztökörnyezet használata; programozás) egy kismintás előmérés [11] eredményei alapján, a négy részteszt feladatait az időkerettel való gazdálkodás miatt három résztesztbe összevonva készült. Az algoritmizálás résztesztje három alkalmazási szinten összesen 32 itemet tartalmazott (Cronbach- $\alpha$ $=0,92)$. A programnyelvi elemek 30 iteme és a fejlesztőkörnyezetre vonatkozó 22 item került közös résztesztbe (Cronbach- $\alpha=0,90)$. Az érettségi jellegü programozási feladat 30 itemet tartalmazott (Cronbach- $\alpha=0,91$ ). Az algoritmizálási (Kolmogorov-Szmirnov $z=1 ; 42 ; p=0,026$ ) és a programozási részteszt $(z=1,551 ; p=0,040)$ eredményei bimodális eloszlást mutatnak, a nyelvi elemek és a felhasználói felület résztesztje normáleloszlásúnak tekinthető $(z=1,11$, n.s.).

A mérésre 2018 tavaszán, a tanévnek az előméréssel [11] megegyező időszakában került sor. Az elömérés adatait a nagymintás vizsgálattól elkülönülten kezeltük. $A$ mérés digitális formában zajlott az első szerző által készített elektronikus tesztrendszerben. [10] [12] A kérdőív kérdései, valamint a tesztitemek többsége - az első négy részteszt itemeinek $92 \%$-a - automatikusan javításra került (egyszeres vagy többszörös választás; halmazba sorolás, rövid válasz), a többi itemet a javítókulcsnak megfelelően a szerzők kézi javítással javították. A programozási feladatok javítása kézzel történt.

\section{Eredmények}

\subsection{A szóolvasás és szövegértés résztesztjének eredményei}

A szóolvasási készség átlagos szintje megfelel az országos mérésekböl ismerteknek, a teljes mintára $\bar{x}=87 \%$ pont, $s=6,4 \%$ pont. A köznyelvi szóolvasás és a szakszókincs olvasása gyengeközepes összefüggést mutat $(r=0,316 ; p<0,001)$, de míg a köznyelvi szavak olvasását mindenki legalább 60 \%pontra teljesítette, addig a szakszókincs résztesztjén a minta közel egyharmada (40 fö) legfeljebb 50 \%pontot ért el. A köznyelvi szavak értésének szintjében nincs lényeges különbség az évfolyamok között ( $\bar{x}=87,7 \ldots 93,8$; ANOVA $F=2,140 ; p=0,138)$, a szakszókincsben a 9 . évfolyam tanulói és az alapszakos hallgatók átlagosan 12,5\%ponttal, szignifikánsan gyengébben teljesítettek, mint a 10-12. évfolyamosok (ANOVA $F=9,379 ; p<0,001$ ). Ez az eltérés érthetö, hiszen ebben a két csoportban vannak azok, akik legrövidebb ideje tanulják a programozást.

A szövegértés teszt átlagos eredménye $\bar{x}=82 \%$ pont ( $s=12,5 \%$ pont), a minta nyolcada (16 fő) ért el $65 \%$ pontnál gyengébb eredményt. Az egyes évfolyamok átlagos eredménye között nincs szignifikáns különbség (ANOVA $F=1,114 ; p=0,096)$. Ennek ellenére a szakszókincs olvasása és a szövegértés eredménye között közepes összefüggés van $(r=0,540 ; p<0,001)$, azaz a szövegértés egyéni különbségei és a szakszókincsben meglévő különbségek együtt járnak. Ezt alátámasztja, hogy a mintát a szakszókincs szóolvasái készsége alapján két részmintára bontva (az 50 \%pontos teljesítményhatár alapján), akkor a két részminta átlaga között jelentős, $15 \%$ pontnyi különbség $(F=2,338 ; p=0,129 ; t=5,908 ; p<0,001)$ van a szövegértésben.

\subsection{Az algoritmizálás eredményei és összefüggései az olvasási képesség összetevőivel}

Az algoritmizálási feladatok résztesztjének átlaga $\bar{x}=43 \%$ pont ( $s=24,5 \%$ pont), a teljesítmények eloszlása kétmóduszú. A bimodalitás oka nem az, hogy programozást most kezdők - a 9. évfolyamra járók és az alapszakos hallgatók - szignifikánsan gyengébben teljesítettek (kezdők $\bar{x}=41,2 \%$ pont; többiek $\bar{x}=44,7 \%$ pont; n.s.). Azzal azonban szignifikáns az algoritmizálás részteszt eredményének összefüggése, hogy hány éve tanul programozni a tesztalany $(r=0,483 ; p<0,001)$. Az 1-2 éve programozók átlaga 22,6 \%pont, a 3-5 éve programozók átlaga 49,0\%pont.

Azok, akik a szakszókincs szóolvasási készségében 50 \%pontnál gyengébben teljesítettek, jelentős és szignifikáns, 20 \%pontnyival alacsonyabb átlaggal oldották meg az algoritmizálás résztesztjét, mint azok, akik a szakszókincset ennél jobban ismerik ( $\bar{x}=29,4 \%$ pont; $s=20,9 \%$ pont ill. $\bar{x}=49,5 \%$ pont; $s=23,5 \%$ pont). Azoknál a mintaalanyoknál viszont, akik a szakszókincs olvasásában meghaladták az 50 \%pontos teljesítményt $(n=88)$, az algoritmizálás eredményessége 
és a szakszókincs szóolvasási készsége között már nincs összefüggés $(r=0,154 ; p=0,155)$. Ez azt jelzi, hogy a szakszókincs filterjelleggel hat az algoritmizálás eredményességére.

A két fenti részminta közötti különbség elsősorban a nehezebb alkalmazási szintekben jelentkezett (2. táblázat). Az értelmezési szint esetén a vártnak megfelelően szórások mindkét részmintában nagyok, a szakszavak olvasásban jobbak esetén nagyobbak az egyéni különbségek.

2. táblázat. Az algoritmizálás átlaga (szórása) az alkalmazási szintek és a szakszavak szóolvasási készsége szerinti bontásban

\begin{tabular}{|c|c|c|c|}
\hline & ráismerés és felidézés & kivitelezés, átkódolás & értelmezés \\
\hline itemszám & 12 & 8 & 12 \\
\hline $\begin{array}{c}\text { szakszókincs } \\
\text { szóolvasás <= 50 \%pont }\end{array}$ & $48,1 \% \mathrm{p}(27,4 \% \mathrm{p})$ & $25,3 \% \mathrm{p}(24,4 \% \mathrm{p})$ & $28,6 \% \mathrm{p}(22,6 \% \mathrm{p})$ \\
\hline $\begin{array}{c}\text { szakszókincs } \\
\text { szóolvasás > 50 \%pont }\end{array}$ & $54,3 \% \mathrm{p}(30,3 \% \mathrm{p})$ & $53,1 \% \mathrm{p}(27,5 \% \mathrm{p})$ & $42,7 \% \mathrm{p}(26,3 \% \mathrm{p})$ \\
\hline különbség & $\begin{array}{c}F=1,15 ; p=0,285 \\
t=1,10 ; p=0,273\end{array}$ & $\begin{array}{c}F=1,77 ; p=0,186 \\
t=5,33 ; p<0,001\end{array}$ & $\begin{array}{c}F=6,63 ; p=0,011 \\
d=3,01 ; p<0,001\end{array}$ \\
\hline
\end{tabular}

Hasonlóan jelentős különbséget okoz a szövegértés nem megfelelő fejlettsége. A szövegértésben 65 \%pont alatt teljesítők jelentősen gyengébben teljesítettek az algoritmizálás résztesztjén, mint a többi tesztalany $(\bar{x}=18,7 \%$ pont; $s=16,4 \%$ pont ill. $\bar{x}=45,8 \%$ pont; $s=23,8$ $\%$ pont; $t=3,84 ; p<0,001)$. A különbség itt is a két magasabb alkalmazási szinten jelentkezett. A szövegértésben legalább 65 \%pontot elérö tanulóknál, hallgatóknál azonban már nincs összefüggés a szövegértés fejlettsége és az algoritmizálás eredménye között $(r=0,167 ; p=0,108)$, azaz a szövegértés is filterjellegü feltétele az algoritmizálásnak.

\subsection{A nyelvi elemek és a felhasználói felület használata résztesztjének eredményei}

A két terület együttes átlaga 52,7\%pont, szórása $s=24,3 \%$ pont (programnyelvi elemek $\bar{x}=$ $54,0 \%$ pont; felhasználói felület $\bar{x}=49,5 \%$ pont) az eredmények normális eloszlásúak. A részteszt két összetevője, azaz a programnyelvi elemek illetve a felhasználó felület használatának eredménye között a korreláció magas $(r=0,703 ; p<0,001)$, ezért az elemzéseket többnyire a két összetevő összevont eredményével végezzük.

Ebből adódóan - a magas korreláció miatt - el kell vetnünk azt a hipotézist, hogy a két összetevő közül bármelyik is filterként hatna a másikra, mert az erős korreláció esetén az összefüggés a változók eloszlásának bármely részén fennáll.

Az eredmény az összevont változónál is - érthetően - közepes erősségű összefüggést mutat azzal, hogy a tesztalany hány éve tanul programozni $(r=0,449 ; p<0,001)$. Az 1-2 éve programozók átlaga 26,7\%pont, a 3-5 éve programozók átlaga 58,2\%pont.

A szakszókincs szóolvasási készsége közepes erösségü összefüggést mutat a két terület együttes átlagával $(r=0,426 ; p<0,001)$. A szakszókincs $50 \%$ pontos határa alapján bontott két részminta átlaga között szignifikáns a különbség $(F=3,751 ; p=0,056 ; t=2,200 ; p=0,030)$. Sem a nyelvi elemek ismerete, sem a felhasználói felület használata nem mutat összefüggést a szövegértéssel ( $r=0,175$ ill. $r=0,160$; n.s.), jelezve, hogy részben szintaktikai, részben technikai elemeket tartalmaz a részteszt, amelyek közvetlenül kevéssé igénylik a szövegértés magas szintjét.

Az algoritmizálás részteszt összetevői közül a kivitelezést $(r=0,423 ; p<0,001)$ és az értelmezést $(r=0,618 ; p<0,001)$ igénylö algoritmus-feladatok mutatnak közepes ill. erős összefüggést a programnyelvi elemek részteszt eredményével. Az eredmény mögött oksági kapcsolatot kevésbé, inkább együttjárást feltételezhetünk: akik mindkét teszten jól teljesítettek, azok feltehetően rutinosabb feladatmegoldók. Ezt részben alátámasztja, hogy ezek a korrelációs együtthatók csökkennek, ha annak a változónak a hatását, hogy hány éve tanulnak programozni a mintaalanyok, parciális korreláció segítségével kontrolláljuk ( $r=0,383$ ill. $r=0,558 ; p<0,001)$.

A programnyelvi elemek és a felhasználói felület résztesztje a feladatok alkalmazási szintje szerinti bontásban a vártnak megfelelő eredményeket mutatja. A magasabb szint felé haladva kismértékben csökken a megoldottság (ráismerés, felidézés: $\bar{x}=55,5 \%$ pont; $s=20,6 \%$ pont; kivitelezés, átkódolás: $\bar{x}=52,4 \%$ pont; $s=23,2 \%$ pont; értelmezés: $\bar{x}=44,6 \%$ pont; $s=21,6 \%$ pont); 
az értelmezési szinté szignifikánsan alacsonyabb, mint a másik két szinté (a kivitelezés, átkódolás szintjével $t=5,38 ; p<0,001)$.

\subsection{A programozási feladat résztesztjén elért eredmények}

A minta bemutatásánál (3.1. fejezet) említetteknek megfelelően a programozás résztesztet 80 fö töltötte ki. A programozás résztesztet kitöltőkre szükített minta első négy résztesztjének eredményeit a (3. táblázat) foglalja össze. A szükített minta átlaga minden részteszt esetében szignifikánsan magasabb, mint a programozás résztesztet nem megírt tanulóké, hallgatóké. Ez a szóolvasás szakszókincs részénél (4.1. fejezet) leírtak, valamint az algoritmizálás, nyelvi elemek és fejlesztőkörnyezet használata esetén megfelel az elvártaknak, a szövegértés esetén pedig annak köszönhető, hogy a gyengének mondható, 65 \%pont alatti szövegértésű tanulók felülreprezentáltak a 9. évfolyamos tanulók és a programozás résztesztet meg nem író öt hallgató részmintájában.

3. táblázat. A programozás résztesztet megoldók átlaga (szórása) az első négy részteszten

\begin{tabular}{|c|c|c|c|}
\hline Szóolvasás & Szövegértés & Algoritmizálás & $\begin{array}{c}\text { Nyelvi elemek, a } \\
\text { fejlesztőfelület használata }\end{array}$ \\
\hline $89,8 \% \mathrm{p}(4,1 \% \mathrm{p})$ & $84,6 \% \mathrm{p}(10,6 \% \mathrm{p})$ & $53,2 \% \mathrm{p}(22,3 \% \mathrm{p})$ & $59,1 \% \mathrm{p}(20,3 \% \mathrm{p})$ \\
\hline
\end{tabular}

Ugyanakkor a szükebb, a programozás részteszt megíró részmintán is fennállnak a 4.1.-4.3. fejezetben leírt legfontosabb megállapítások:

- A szakszókincs szóolvasásában legfeljebb 50 \%pontot elérök a szövegértés részteszten szignifikánsan alacsonyabb átlagot értek el, mint az 50 \%pont felettiek ( $\bar{x}=79,2 \%$ pont ill. $\bar{x}$ $=88,3 \%$ pont; $F=0,006 ; p=0,937 ; t=3,172 ; p=0,002$ ).

- Szignifikáns az algoritmizálás részteszt eredményének összefüggése azzal, hogy hány éve tanul programozni a tesztalany $(r=0,501 ; p<0,001)$. Az 1-2 éve programozók átlaga 34,0 \%pont, a 3-5 éve programozók átlaga 55,0 \%pont.

- A szakszókincs szóolvasásában legfeljebb 50 \%pontot elérők az algoritmizálás résztesztjén átlagosan 11,1 \%ponttal gyengébben teljesítettek, mint a szakszókincs olvasásában jól teljesítök ( $\bar{x}=44,1 \%$ pont; $s=21,7 \%$ pont ill. $\bar{x}=55,2 \%$ pont; $s=22,0 \%$ pont; $F=0,034 ; p=$ $0,854 ; t=2,132 ; p=0,036)$. A különbség elsősorban az algoritmizálás részteszt kivetelezési, átkódolási szintjében jelentkezett (a két részminta átlagának különbsége 18,3 \%pont).

- Fennáll a szakszókincs filterjellege: Azoknál, akik a szakszókincs olvasásában meghaladták az 50 \%pontos teljesítményt, az algoritmizálás eredményessége és a szakszókincs szóolvasási készsége között már nincs összefüggés $(r=0,147 ; p=0,241)$.

- A szövegértés részteszten 65 \%pont alatt teljesítők jelentősen, átlagosan 15,7 \%ponttal alacsonyabb átlagot értek el az algoritmizálás részteszten, mint a jobb szövegértők. A szövegértés filterjellege is fennáll: a $65 \%$ pont feletti szövegértés-eredményt elérők esetén nincs szignifikáns összefüggés a szövegértés és az algoritmizálás eredménye között ( $r=$ $0,121 ; p=0,296)$.

- A programnyelvi elemek és a fejlesztöfelület használatának résztesztje gyenge-közepes korrelációt mutat a szakszavak olvasási készségével $(r=0,314 ; p=0,005)$, de nincs összefüggésben a szövegértés fejlettségével $(r=0,002 ; p=0,989)$.

- Az algoritmizálás részteszt összetevői közül a kivitelezést $(r=0,318 ; p=0,006)$ és az értelmezést $(r=0,499 ; p<0,001)$ igénylö algoritmus-feladatok mutatnak gyenge-közepes összefüggést a programnyelvi elemek részteszt eredményével.

A programozás részteszten teszteredmények átlaga $\bar{x}=72,1 \%$ pont, az eloszlás bimodális (Kolmogorov-Szmirnov $z=1,551 ; p=0,040$ ). Az évfolyamok átlaga között nincs szignifikáns különbség (ANOVA $F=2,079 ; p=0,167$ ), az évfolyamok szerinti átlagok $70,1 \%$ pont és $74,3 \%$ pont közöttiek. Azzal sem függ össze szignifikánsan a programozás részteszt eredménye, hogy hány éve tanul programozni a tanuló vagy hallgató $(r=0,218 ; p=0,053)$.

A programozás részteszt eredménye az első négy részteszt eredményei közül a programnyelvi elemek és a felhasználói felület alkalmazása részteszttel mutat erős $(r=0,612 ; p<$ $0,001)$, az algoritmusok részteszt értelmezési szintjével pedig gyenge-közepes $(r=0,292 ; p=0,011)$ összefüggést. Az első négy részteszt összes itemével mint független változókkal végzett lineáris regresszióanalízis eredménye szerint a programozás részteszt varianciájának 93,7 \%-át 
magyarázza az itemek varinaciája $\left(R^{2}=0,937 ; F=10,565 ; p<0,001\right)$, azaz a négy részteszt együttesen jól jelzi a programozás részteszt várható egyéni különbségeit.

\subsection{Az algoritmizálás és a programnyelvi elemek, felhasználói felületek résztesztjének kapcsolat a programozással}

A 4.4. fejezethez hasonlóan az elemzés e részében is csak a programozás résztesztet megoldó 80 fö adatait vizsgáljuk.

A részmintán az algoritmizálás $60 \%$ pontos szintje filterként müködik a programnyelvi elemek és a felhasználói felület résztesztjére, mivel a szintet el nem érők $\left(n_{1}=40 ; \bar{x}=52,5 \%\right.$ pont; $s=19,3$ \%pont) szignifikánsan gyengébben ( $F=0,032 ; p=0,859 ; t=3,046 ; p=0,003)$ teljesítettek a programnyelvi elemek és felhasználói felület résztesztjén, mint az algoritmizálás $60 \%$ pontos szintjét meghaladók ( $n_{2}=40 ; \bar{x}=65,7 \%$ pont; $s=19,4 \%$ pont), ugyanakkor a szintet meghaladók esetén az algoritmizálás egyéni különbségei már nem hatnak szignifikánsan a programnyelvi elemek, felhasználói felület használata egyéni különbségeire $(r=0,253 ; p=0,083)$.

A nyelvi elemek és a felhasználói felület használata résztesztjének két összetevőjével kapcsolatban a 4.3. fejezetben írtaknak megfelelően el kell vetnünk a filterjelleg hipotézisét. A programozás résztesztet megoldók esetén a két összetevő között a teljes mintáénál magasabb $r=$ 0,711 a korrelációs együttható értéke.

A magas korreláció $(r=0,612 ; p<0,001)$ következményeként a programnyelvi elemek, felhasználói felület használat részteszt és a programozás részteszt eredménye között sem igazolható a filterjelleg. Az eredmények azt jelzik, hogy a három terület fejlettsége erősen együtt jár.

Ugyanakkor az algoritmizálás a programozásra is filterjellegúen hat: az algoritmizálás részteszten $60 \%$ pont alatt teljesítő 40 fö átlagosan szignifikánsan gyengébben teljesített a programozás teszten, mint a $60 \%$ pontot meghaladó eredményü 40 fö ( $\bar{x}=64,6 \%$ pont; $s=25,3 ; \bar{x}$ $=76,6 \%$ pont; $s=22,4 ; F=2,503 ; p=0,118 ; t=2,952 ; p=0,007)$, de a $60 \%$ pontot meghaladó teljesítményű algoritmizálás esetén már nincs összefüggés a programozás teszt eredményével ( $r=$ 0,$157 ; p=0,332$ ).

\section{Következtetések}

A szóolvasás készségében mérhető egyéni különbségek - a készség magas átlaga miatt nem magyarázzák a szövegértés különbségeit, ugyanakkor a szakszavak szóolvasásával erősen összefügg a szövegértés képessége. Feltételezhető, hogy mindkettőben általános tanulási képességek és motívumok hatása jelentkezik.

Mind a szakszavak szóolvasási készsége, mind a szövegértés filterjellegüen hat az algoritmizálás képességére, azaz mindkét esetben megadható a 2. fejezetben leírt küszöbérték. A különbségek - érthetően - elsősorban az algoritmizálás magasabb alkalmazási szintjén, a kivitelezési-átkódolási, illetve az értelmezési szinten jelentkeztek.

Az algoritmizálás készségének fejlettsége filterként hat mind a programnyelvi elem és fejlesztő felület használata résztesztjének, mind a programozásnak a fejlettségére. Jelentös a különbség az algoritmizálásban $60 \%$ pont alatt teljesítők és az ennél jobb eredményt elérők között. A programnyelvi elemek helyes használata, a fejlesztőfelület alkalmazása és a programozás fejlettsége erősen együtt jár.

Az eredmények együttesen igazolják azt a tapasztalatokra épülő módszertani ajánlást, hogy az algoritmizálás készségének kialakítása, és vele párhuzamosan a szakszavak elsajátítása a sikeres programozásnak kritikus előfeltételei. Fontos azonban, hogy a jelen tanulmányban leírt eredmények nem veszik figyelembe sem az általános tanulási képességek, sem a tanulási motiváció elemeinek fejlettségét. Vizsgálatainkat ezen tényezők figyelembe vételével szeretnénk bővíteni további kutatásaink során.

\section{Köszönetnyilvánítás}

A vizsgálat a második szerző középiskolai kutatótanári programjának része. A szerzők köszönetet mondanak a közremüködő intézmények (Kecskeméti Bányai Júlia Gimnázium, 
Kecskeméti Bolyai János Gimnázium, Neumann János Egyetem GAMF Műszaki és Informatikai Kar) tanulóinak, hallgatóinak és oktatóinak.

Köszönettel tartozunk a kutatás támogatásáért, amely az EFOP-3.6.1-16-2016-00006 „A kutatási potenciál fejlesztése és bővítése a Neumann János Egyetemen" pályázat keretében valósult meg. A projekt a Magyar Állam és az Európai Unió támogatásával, az Európai Szociális Alap társfinanszírozásával, a Széchenyi 2020 program keretében valósul meg.

\section{Irodalomjegyzék}

[1] CodeWeek: Why learn to code? [Online]. Elérhető: http://codeweek.eu [Megtekintés: 12-Oct-2020].

[2] Feurzeig, W., Horwitz, P. \& Nickerson, R. S.: Microcomputers in education (Report No. 4798). Prepared for: Department of Health, Education, and Welfare; National Institute of Education; and Ministry for the Development of Human Intelligence, Republic of Venezuela. Bolt Beranek \& Newman, Cambridge, MA, October (1981).

[3] Johanyák, Zs. Cs., Pap-Szigeti, R. \& Alvarez, G. R. P.: Analyzing students' programming failures. A GAMF Közleményei, No. 22. (2008) pp. 115-120.

[4] Kelemen Rita: A matematikai szövegesfeladat-megoldó képesség vizsgálata többségi és tanulásban akadályozott 9-13 éves tanulók körében. PhD értekezés, Neveléstudományi Doktori Iskola, Szegedi Tudományegyetem, Szeged (2010).

[5] Kiss Róbert: Robotika a közoktatásban. Gradus, Vol. 2. No. 2. (2015) pp. 81-93.

[6] Kurland, D. M., Pea, R. D., Clement, C. \& Mawby, R.: The Study of the Development of Programming Ability and Thinking Skills in High School Students. In: Soloway, E. \& Spohrer, J. C. (eds.): Studying the Novice Programmer. Lawrence Erlbaum Associates, Inc., Hillsdale, New Jersey, USA (1981). pp. 83-112.

[7] Lahtinen, E., Ala-Mutka, K. \& Järvinen, H.: A study of the difficulties of novice programmers. Proceedings of the 10th annual SIGCSE conference on Innovation and technology in computer science education ITiCSE '05. New York, NY, USA (2005). pp. 14-18. DOI: 10.1145/1067445.1067453

[8] Lehrer, R., Guckengerg. T. \& Sancilio, L.: Influences on LOGO on children's intellectual development. In: Mayer, R. E. (ed.): Teaching and learning computer programming: Multiple research perspectives. Lawrence Erlbaum Associates, Inc., Mahwah, New Jersey, USA (1988). pp. 75-110.

[9] Pap-Szigeti, R.: Cooperative Strategies in Teaching of Web-Programming. Practice and Theory in Systems of Education, Vol. 2. No. 3-4. (2007) pp. 51-64.

[10] Pap-Szigeti Róbert: A programozási készségek vizsgálata középiskolában és a felsőoktatásban. Gradus, Vol. 4. No. 1. (2017) pp. 216-222.

[11] Pap-Szigeti Róbert: Szoftver- és mérőeszköz-fejlesztés programozási ismeretek és készségek értékelésére. Gradus, Vol 5. No. 2. (2018) pp. 355-359.

[12] Pap-Szigeti Róbert - Török Erika - Tánczikné Varga Szilvia: Kérdőívek és tesztek elektronikus felvételét támogató szoftver fejlesztése és alkalmazása. In: Fodorné Tóth Krisztina (szerk.): A felsőoktatási lifelong learning társadalmi és gazdasági haszna: kutatás - fejlesztés - innováció. MELLearN Felsőoktatási Hálózat az életen át tartó tanulásért Egyesület, Pécs (2018) pp. 21-29.

[13] Pásztor,A., Pap-Szigeti, R. \& Török, E.: Effects of Using Model Robots in the Education of Programming. Informatics in Education, Vol. 9. No. 1. (2010) pp. 133-140. DOI: 10.15388/infedu.2010.08s

[14] Pásztor Attila, Török Erika, Pap-Szigeti Róbert: Innovatív informatikai eszközök és módszerek a programozás oktatásban. Gradus, Vol. 1. No. 1. (2014) pp. 22-27.

[15] Pea, R. D. \& Kurland, D. M.: On the cognitive effects of learning computer programming. New Ideas in Psychology, Vol. 2. No. 2. (1984) pp. 137-168. DOI: 10.1016/0732-118X(84)90018-7

[16] Robins, A., Rountree, J. \& Rountree, N.: Learning and Teaching Programming: A Review and Discussion. Computer Science Education, Vol. 13. No. 2. (2003). pp. 137-172. DOI: 10.1076/csed.13.2.137.14200

[17] Törley Gábor: Algoritmus vizualizáció a tanítási gyakorlatban. (2013) [Online] Elérhető: http://real.mtak.hu/31528/1/TG_alg_viz_tan_gyak.pdf [Megtekintés: 23-Aug-2020] 